\title{
Response of Bacterial Community Structure to Different Biochar Addition Dosages in Karst Yellow Soil Planted with Ryegrass and Daylily
}

\author{
Songping Luo ${ }^{1,2}$, Binghui He ${ }^{1, *}$, Dandan Song ${ }^{1}$, Tianyang $\mathrm{Li}^{1}$, Yaopeng $\mathrm{Wu}^{1}$ and Lei Yang ${ }^{3}$ \\ 1 College of Resources and Environment, Southwest University, Chongqing 400715, China; \\ luosongping234@126.com (S.L.); songdandan92@163.com (D.S.); tyli53@swu.edu.cn (T.L.); \\ qihuan2008@email.swu.edu.cn (Y.W.) \\ 2 Guizhou Technology Consulting Research Center of Soil and Water Conservation, Guiyang 550002, China \\ 3 State Key Laboratory of Urban and Regional Ecology, Research Center for Eco-Environmental Sciences, \\ Chinese Academy of Sciences, Beijing 100085, China; leiyang@rcees.ac.cn \\ * Correspondence: hebinghui@swu.edu.cn; Tel.: +86-23-68251249
}

Received: 11 February 2020; Accepted: 5 March 2020; Published: 9 March 2020

\begin{abstract}
Biochar has been widely used to ameliorate soil quality and increase crop productivity through enhancement of nutrient availability and microbial community. The Karst yellow soil in China is characterized by severe soil degradation owing to intensive nutrient leaching. However, the biochar addition effects on the changes of Karst yellow soil are unclear, and the adequate number of biochar dosages to explain optimum of plant growth in this soil area remains poorly understood. In this study, pot experiments were conducted to examine the effects of biochar addition $(1 \%, 3 \%$, $5 \%, 7 \%$, and $9 \%$ by weight; $0 \%$ as a control) on bacterial abundance and community structure via high-throughput sequencing coupled with bioinformatics methods applied to Karst yellow soil with planting ryegrass (Lolium perenne L.) and daylily (Hemerocallis fulva). After adding biochar for 188 days, significantly increased $\mathrm{pH}$, soil organic matter, total nutrient contents, and bacterial abundance, but decreased available nitrogen, were observed. Changed bacterial community structures were found in biochar treatments compared with those without biochar. In both soils of planted ryegrass and daylily, the optimum soil bacterial abundance was found in $7 \%$ biochar dosage, but the lowest values were in the controls $(0 \%)$. Taxonomic analysis identified that Micrococcaceae $(24.53 \%)$, Oxalobacteraceae $(11.87 \%)$, and Nocardioidaceae $(7.89 \%)$ were the dominant family in the soil of ryegrass growth, and Micrococcaceae $(16.20 \%)$, Xanthomonadaceae $(6.94 \%)$, and Nocardioidaceae $(6.41 \%)$ were the dominant family in soil of daylily growth. Canonical correspondence analysis showed that the alterations of soil bacterial abundance and community were highly interrelated with soil chemical properties. The results provided a better understanding of the mechanisms underlying the plant-soil microbe interactions and their responses to biochar dosages in low fertility soil regions.
\end{abstract}

Keywords: biochar; bacterial community structure; yellow soil; illumine MiSeq sequencing

\section{Introduction}

Biochar is a carbon-rich by-product produced by pyrolysis of organic biomass at the temperatures $\left(300-1000^{\circ} \mathrm{C}\right)$ in a low or almost zero oxygen environment $[1,2]$. Biochar amendment to soil is a widely used method to enhance soil quality and soil fertility [3,4], caused by some beneficial properties of biochar, such as large inner surface area with high porosity, high organic $\mathrm{C}$, adsorption capacity, and high $\mathrm{pH}[5,6]$. Previous studies found that biochar-amended soils had emerged as a promising technology to ensure the sustainability of agricultural system via increasing soil moisture and nutrient, providing beneficial microenvironments to host microorganisms and improving plant growth [7-10]. 
Biochar addition is not only considered as an organic fertilizer, but also an environmental application of climate change mitigation [1].

Published literature found that biochar can be a good soil conditioner that changes the agricultural environment by positively or negatively affecting the soil microbial communities [11]. Microbial communities have significant influences on soil ecosystem services, including soil stability, food security, carbon storage capacity, and nutrient cycling [12]. Biochar affects soil fertility as microbes could mediate many processes of nutrient cycling [13,14]. Some properties of biochar, for example, minerals, free radicals, and volatile organic compounds (VOCs), could result in changing the habitats of soil microbes and directly affecting microbial metabolisms, which together lead to altering microbial activity and microbial community structures [15-17]. Another potential benefit of biochar application is related to microbiological processes including stimulate soil microbial activity, for example, enhanced the plant growth activities improving organisms in the rhizosphere, as well as elevated the levels of root colonisation of mycorrhizae [18-20]. The effects of biochar addition on soil ecosystem were varied with soil types. In current studies, soil types such as saline soils, acid soils, low organic carbon soil, and nutritionally unbalanced soil were selected to study the response of soil ecosystem functions to biochar application, and numerous results were found [21-23]. For example, after 96 days' treatment, the forest litter-derived biochar altered the soil bacterial community and enriched bacterial diversity [24]. The study found that the bacterial density increased by $16 \%$ after adding biochar for four weeks in a sandy loam soil [25]. Conversely, no effect of biochar was identified for the parameters considered except for $\mathrm{pH}$ after 14 months' incubation in a wheat crop [26]. Thus, evaluating the effect of biochar on plant nutrient uptake is a beneficial tool for sustainable agriculture [27].

Yellow soil as a Dystric Luvisol (Ultisols) is widely distributed in south Karst China, where it occupies 12\% Karst area of the global land area [28]. Karst rocky desertification is one of the most and increasingly more serious environmental problems in China [29,30]. In this region, soil erosion and organic carbon loss have threated the sustainability of agricultural development and food security [31]. Soil quality and sustainability are damaged by intensive agricultural production, relying on inorganic fertilizers in many places [32], including the Guizhou province, which is covered with large areas of fragile Karst mountainous [33]. Thus, it is urgent to explore effective ways to improve soil fertility and crop yields, and build an environmental-friendly agricultural system in this region, in which the thin soil layer and low fertility of the yellow soils influenced the survival and development of 67.5 million impoverished people. Owing to the potential benefits of biochar, recent studies proved that biochar addition to low fertility soils is a promising technology to improve crop production [34]. Biochar could serve as a nutrient source to regulate uptake of plant root nutrient and indirectly change soil nutrient content [35], and plants growing in the soil with biochar addition will have a complex process in soil-plant systems [36]. Evidence shows that the first response to biochar particles and plants is roots, because biochar addition influences plant growth by directly changing soil properties and indirectly altering soil moisture and nutrient conditions [35,37]. This is especially true in Karst yellow soils. Studies describing the biochar dose-response to the plants and soils are few and generally lack application of a large number of dosages to explain plants' growth optima [38,39].

In this study, yellow soil was used to test biochar dosage effects on soil bacterial abundance, bacterial community structure, and soil nutrients. The study aimed to explore the response of soil bacterial communities to biochar addition and the optimal biochar addition dosages, which would be beneficial for soil bacteria and substantially impact the soil-plant interactions. We hypothesized that (1) biochar treatments could improve soil chemical properties; (2) the soil bacterial abundance and community structure would be changed after biochar addition. 


\section{Materials and Methods}

\subsection{Soil and Pretreatment}

The pot experiment was conducted in the greenhouse of key laboratory of the Three Gorges Reservoir Region's Eco-Environment, Ministry of Education, Southwest University, China. The soil used for the pot experiment was collected in Yaxi $\left(27^{\circ} 37^{\prime} \mathrm{N}, 106^{\circ} 37^{\prime}\right.$ E) in southwest Karst area of Guizhou province, China. This sampling site has a typical mid-subtropical warm humid monsoon climate with an average annual rainfall of $1043.4 \mathrm{~mm}$, and the annual mean temperature was $14.6^{\circ} \mathrm{C}$. The soil thickness of the sampling site is 50 to $70 \mathrm{~cm}$. The soil in this area has low organic matter and fertility. Soil samples were collected from the plough layer (i.e., 0-30 cm depth) in August 2016. The collected soil was air-dried, removing roots, stones, litter, and debris to pass through $5 \mathrm{~mm}$ and $2 \mathrm{~mm}$ mesh sieves, and then homogenized and stored at room temperature $\left(25^{\circ} \mathrm{C}\right)$ one week before pot experimental use.

Biochar used in the study was produced from apple wood (Malus pumila Mill.) at a pyrolysis temperature of $475^{\circ} \mathrm{C}$ with oxygen deprivation condition (Yixin Bio-energy technology development Co., Shanxi, China). Biochar was stored in a dry and aerobic environment as well as milled to pass through a $2 \mathrm{~mm}$ sieve before further use. The surface area of biochar was measured by the BET (the basic Brunaeur, Emmett, and Teller approach to multimolecular gas adsorption) method with a TriStar 3000 analyser (micromeritics). The chemical characteristics of biochar are listed in Table 1.

Table 1. Chemical properties of the apple branch biochar (BC) used in the study.

\begin{tabular}{ccccccccc}
\hline $\mathbf{p H}$ & $\begin{array}{c}\text { TP } \\
\mathbf{g ~ k g}^{-1}\end{array}$ & $\begin{array}{c}\text { AP } \\
\mathbf{g ~ k g}\end{array}$ & $\begin{array}{c}\text { TK } \\
\mathbf{g ~ k g}^{-1}\end{array}$ & $\begin{array}{c}\text { AK } \\
\mathbf{g ~ k g}^{-1}\end{array}$ & $\begin{array}{c}\text { CEC } \\
\mathbf{c m o l ~ k g}^{-1}\end{array}$ & $\begin{array}{c}\text { TCa } \\
\mathbf{g ~ k g}^{-1}\end{array}$ & $\begin{array}{c}\text { TMg } \\
\mathbf{g ~ k g}^{-1}\end{array}$ & $\begin{array}{c}\text { Surface } \\
\text { Area } \\
\mathbf{m}^{\mathbf{2}} \mathbf{g}^{-1}\end{array}$ \\
\hline $10.09 \pm 0.05$ & $16.17 \pm 0.19$ & $0.20 \pm 0.01$ & $60.11 \pm 0.31$ & $16.55 \pm 0.07$ & $10.26 \pm 0.39$ & $37.88 \pm 1.16$ & $11.43 \pm 0.16$ & $17.20 \pm 1.31$ \\
\hline
\end{tabular}

TP, AP, TK, AK, CEC, TCa, and TMg indicate total phosphorus, available phosphorus, total potassium, available potassium, cation exchange capacity, total calcium, and total magnesium, respectively. Values are the means of three replicates \pm SEM (standard error of the mean).

\subsection{Experimental Design}

Soil was carefully mixed with biochar before filling the pots, and then placed in a container of the polyvinyl chloride (PVC) pots $(0.22 \mathrm{~m}$ in diameter at the top, $0.185 \mathrm{~m}$ in diameter at the bottom, and $0.215 \mathrm{~m}$ high). Some of the soil samples were air-dried, and analyzed to obtain soil chemical properties. The two plant types, ryegrass (Lolium perenne L.) and daylily (Hemerocallis fulva), were planted in the pots at $0 \%, 1 \%, 3 \%, 5 \%, 7 \%$, and $9 \%$ mass ratios of biochar to soil during a 188-day incubation study period (Figure 1). The ryegrass $(\mathrm{T})$ is a pasture and turf grass and daylily $(\mathrm{H})$ is a vegetable and cash crop with high adaptability in the Karst region. The biochar addition was 0\% (control, T0/H0), 1\% (T1/H1), 3\% (T2/H2), 5\% (T3/H3), 7\% (T4/H4), and 9\% (T5/H5), respectively. Seeds of ryegrass were sown at twenty seeds per pot, and with a similar growth state, seedlings of daylily were planted for pot treatments. The treatments were replicated three times with a completely randomized design. During the experimental period, the air temperature was sustained at $22{ }^{\circ} \mathrm{C}$ to $25{ }^{\circ} \mathrm{C}$, and the relative humidity was maintained at $78 \%$ in the greenhouse. The pots were made up of a capped bottom and air outlet tubing at the basis with some limestone. The plants were irrigated at an interval of seven days with distilled water, providing to keep the soil moisture content at $65 \%$ of field capacity. Soil samples from the pot experiments were collected and put in the centrifuge tubes separately, and then kept in a refrigerator at $-20{ }^{\circ} \mathrm{C}$ for further analysis. 


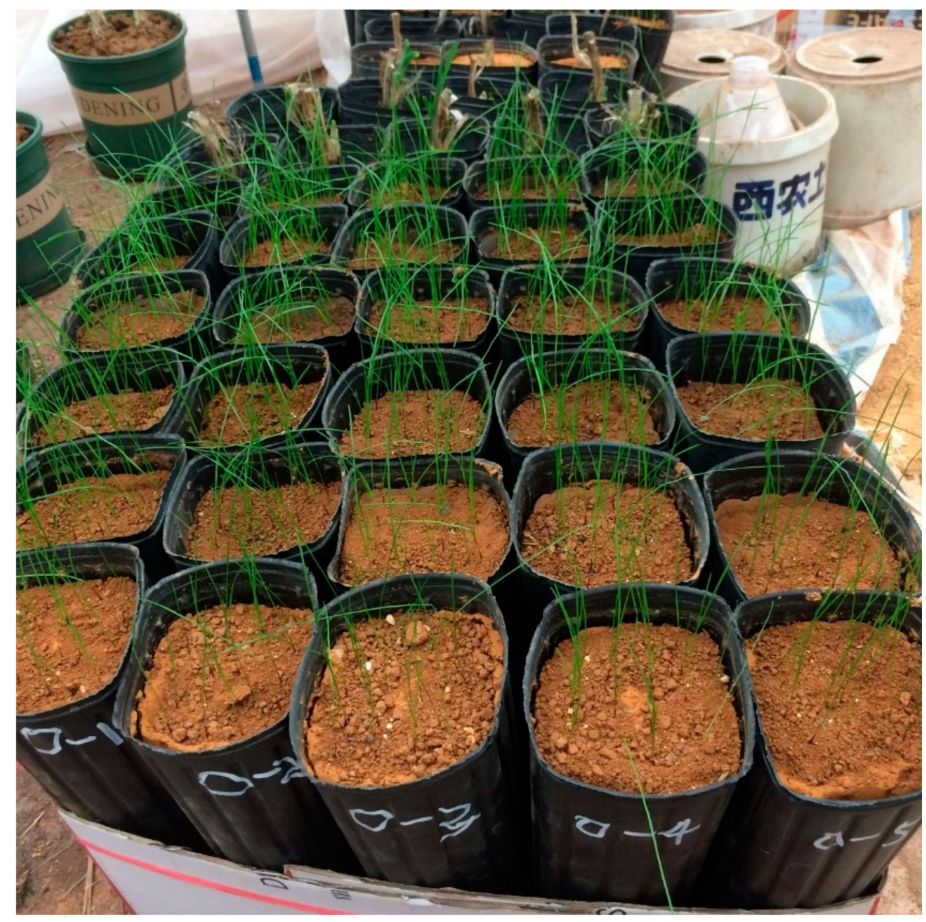

Figure 1. A photo of the pot experiment.

\subsection{Soil Chemical Properties}

Soil pH was measured at 1:2.5 (weight/volume) soil-water ratio [40]. Soil organic matter (SOM) was measured by the potassium dichromate oxidation-external heating method [41]. Soil total nitrogen (TN) was measured by a VarioMax $\mathrm{CN}$ analyser (Elementar Analysensysteme GmbH, Germany). Available nitrogen (AN) was extracted using $2 \mathrm{M} \mathrm{KCl}$ at a 1:5 v/v ratio of samples to $\mathrm{KCl}$ and colorimetric analysis of $\mathrm{NO}_{3}{ }^{-}$using the vanadate method [42]. Soil total phosphorus (TP) was determined by the molybdenum-blue method fused using sodium hydroxide. Soil available phosphorus (AP) was determined using the molybdenum-blue method extraction by sodium bicarbonate. Soil total potassium (TK) was determined with fused using sodium hydroxide and then measured by atomic absorption flame spectrophotometry. Soil available potassium (AK) was extracted by ammonium acetate and then measured by flame spectrophotometry [40].

\subsection{Soil DNA Extraction and PCR (Polymerase Chain Reaction) Amplification}

Soil DNA of each treatment was extracted in triplicate $(0.5 \mathrm{~g})$ from the soil in each pot using the Fast DNA ${ }^{\circledR}$ SPIN Kit for soil (MP Biomedicals, Solon, OH, USA). The extraction protocols followed the manufacturer's instructions. The total soil DNA samples were obtained and stored at $-8^{\circ} \mathrm{C}$ for further bioinformatics analysis. The $16 \mathrm{~S}$ rDNA V3-V4 regions of the Eukaryotic ribosomal RNA gene were amplified by PCR $\left(95^{\circ} \mathrm{C}\right.$ for $2 \mathrm{~min}$, followed by 27 cycles at $98{ }^{\circ} \mathrm{C}$ for $10 \mathrm{~s}, 62^{\circ} \mathrm{C}$ for $30 \mathrm{~s}$, and $68^{\circ} \mathrm{C}$ for $30 \mathrm{~s}$, and a final extension at $68^{\circ} \mathrm{C}$ for $10 \mathrm{~min}$ ) using the primers 341F (CCTAYGGGRBGCASCAG) and 806R (GGACTACNNGGGTATCTAAT). The barcode is an eight-base sequence unique to each sample. In addition, PCR reactions were performed in triplicate $50 \mu \mathrm{L}$ mixture containing $5 \mu \mathrm{L}$ of $10 \times \mathrm{KOD}$ Buffer, $5 \mu \mathrm{L}$ of $2.5 \mathrm{mM}$ dNTPs (Deoxyribonucleoside triphosphates), $1.5 \mu \mathrm{L}$ of each primer $(5 \mu \mathrm{M})$, $1 \mu \mathrm{L}$ of KOD polymerase, and $100 \mathrm{ng}$ of template DNA. The PCR reaction of bacterial 16s DNA gene hypervariable V3-V4 regions was determined by a Qubit 3.0 fluorometer.

\subsection{Sequence Processing and Bioinformatics Analysis}

After DNA extraction, amplicons were extracted from $2 \%$ agarose gels and purified using the AxyPrep DNA Gel Extraction Kit (Axygen Biosciences, Union City, CA, U.S.) according to the 
manufacturer's instructions, and quantified using the QuantiFluor -ST (Promega, U.S.) and normalized. Purified amplicons were pooled in equimolar and paired-end sequenced $(2 \times 250)$ on an Illumina platform according to the standard protocols. To get high quality clean reads, raw reads were further filtered based on removing reads containing more than $10 \%$ of unknown nucleotides $(\mathrm{N})$ and removing reads containing less than $80 \%$ of bases with quality (Q-value) $>20$. Paired-end clean reads were merged as raw tags using FLASH (Fast Length Adjustment of SHort reads) with a minimum overlap of $10 \mathrm{bp}$ and mismatch error rates of $2 \%$ [43]. Apart from that, the effective tags were clustered into operational taxonomic units (OTUs) of $\geq 97 \%$ similarity using UPARSE pipeline [44]. The tag sequence with the highest abundance was selected as the reprehensive sequence within each cluster. Venn analysis was performed in R software ( $\mathrm{v}$ 3.2.1) to identify unique and common OTUs [45]. The representative sequences were classified into organisms by a naive Bayesian model using RDP (Ribosomal Database Project) classifier (Version 2.2) based on the SILVA database (https://www.arb-silva.de/) [46,47]. The abundance statistics of each taxonomy and phylogenetic tree was construction in a Perl script and visualized using SVG (Scalable Vector Graphics). Chao1, Simpson and all other alpha diversity index were calculated in QIIME (Quantitative Insights Into Microbial Ecology) [48]. OTU rarefaction curves and species' rank-abundance curves were plotted in QIIME. Weighted and unweighted unifrac distance matrix was generated by QIIME. The composition of bacteria was analysed using a weighted pair-roup method with arithmetic mean (UPGMA) cluster analysis according to weighted Unifrac distances for comparison of bacterial community composition in different treatments.

\subsection{Statistical Analysis}

Significant differences in soil chemical properties, bacterial alpha diversity, and bacterial relative abundances among samples were tested by one-way analysis of variance (ANOVA) combined with Duncan's-test. Above-mentioned analyses were performed using SPSS version 24. Statistics of between group Alpha index comparison was examined by a Welch's t-test and a Wilcoxon rank test in R software [45]. Alpha index comparing groups was determined by a Tukey's HSD test and a Kruskal-Wallis H test in R. Canonical correspondence analysis (CCA) was used to determine which environmental factors are most frequently linked to bacterial communities by CANOCO version 4.5.

\section{Results}

\subsection{Soil Chemical Properties}

Changes in soil chemical properties showed similar trends between two planted soils (Table 2). Specifically, soil $\mathrm{pH}, \mathrm{AP}, \mathrm{TK}$, and AK increased with the increasing of biochar dosages from $0 \%(\mathrm{CK})$ to $9 \%$. SOM, TN, and TP increased from $0 \%$ (CK) to $7 \%$ biochar addition, but decreased in the $9 \%$ biochar addition, while AN content showed the opposite trend (Table 2). In general, compared with the controls, all the soil nutrient contents of biochar treatments were higher, except AN (Table 2). 
Table 2. Soil chemical properties planted with ryegrass $(\mathrm{T})$ and daylily $(\mathrm{H})$ at different biochar addition rates in the studying pots.

\begin{tabular}{|c|c|c|c|c|c|c|c|c|}
\hline Treatments & $\mathrm{pH}$ & $\begin{array}{c}\mathrm{SOM} \\
\mathrm{g} \mathrm{kg}^{-1}\end{array}$ & $\begin{array}{c}\mathrm{TN} \\
\mathrm{g} \mathrm{kg}^{-1}\end{array}$ & $\begin{array}{c}\mathrm{AN} \\
\mathrm{g} \mathrm{kg}^{-1}\end{array}$ & $\begin{array}{c}\mathrm{TP} \\
\mathrm{g} \mathrm{kg}^{-1}\end{array}$ & $\begin{array}{c}\text { AP } \\
\mathrm{cmol} \mathrm{kg}^{-1}\end{array}$ & $\begin{array}{c}\text { TK } \\
\mathrm{g} \mathrm{kg}^{-1}\end{array}$ & $\begin{array}{c}\mathrm{AK} \\
\mathrm{g} \mathrm{kg}^{-1}\end{array}$ \\
\hline T0 (CK) & $5.42 \pm 0.02 \mathrm{e}$ & $5.88 \pm 0.75 d$ & $0.52 \pm 0.01 c$ & $38.25 \pm 2.79 a$ & $0.19 \pm 0.01 \mathrm{f}$ & $0.34 \pm 0.05 f$ & $20.4 \pm 0.15 c$ & $0.05 \pm 0.01 \mathrm{f}$ \\
\hline $\mathrm{T} 1$ & $5.49 \pm 0.06 e$ & $7.71 \pm 0.23 \mathrm{~d}$ & $0.44 \pm 0.02 \mathrm{~d}$ & $26.02 \pm 2.31 b$ & $0.21 \pm 0.01 \mathrm{e}$ & $0.76 \pm 0.09 \mathrm{e}$ & $20.2 \pm 0.1 \mathrm{~cd}$ & $0.42 \pm 0.01 \mathrm{e}$ \\
\hline $\mathrm{T} 2$ & $6.00 \pm 0.02 d$ & $7.98 \pm 0.61 d$ & $0.55 \pm 0.01 c$ & $22.40 \pm 2.41 b c$ & $0.21 \pm 0.01 \mathrm{~d}$ & $1.07 \pm 0.05 \mathrm{~d}$ & $19.9 \pm 0.22 d$ & $1.06 \pm 0.02 \mathrm{~d}$ \\
\hline T3 & $7.31 \pm 0.02 c$ & $22.39 \pm 1.14 c$ & $0.70 \pm 0.01 b$ & $21.05 \pm 0.55 b c$ & $0.25 \pm 0.01 c$ & $1.83 \pm 0.05 c$ & $22.2 \pm 0.31 b$ & $2.06 \pm 0.05 c$ \\
\hline $\mathrm{T} 4$ & $7.57 \pm 0.04 b$ & $29.99 \pm 0.68 a$ & $1.03 \pm 0.01 \mathrm{a}$ & $20.59 \pm 3.24 c$ & $0.38 \pm 0.02 \mathrm{a}$ & $2.13 \pm 0.09 b$ & $22.4 \pm 0.14 b$ & $2.40 \pm 0.31 b$ \\
\hline $\mathrm{T} 5$ & $7.90 \pm 0.04 a$ & $25.13 \pm 2.18 b$ & $0.69 \pm 0.01 b$ & $21.72 \pm 2.54 b c$ & $0.34 \pm 0.01 b$ & $2.32 \pm 0.11 a$ & $23.8 \pm 0.27 a$ & $3.57 \pm 0.08 \mathrm{a}$ \\
\hline H0 (CK) & $5.45 \pm 0.02 \mathrm{e}$ & $3.25 \pm 0.32 f$ & $0.50 \pm 0.01 \mathrm{f}$ & $52.27 \pm 0.56 a$ & $0.23 \pm 0.06 c$ & $0.34 \pm 0.05 d$ & $19.4 \pm 0.06 c$ & $0.06 \pm 0.01 \mathrm{f}$ \\
\hline H1 & $5.48 \pm 0.06 \mathrm{e}$ & $8.47 \pm 0.95 \mathrm{e}$ & $0.60 \pm 0.03 e$ & $46.16 \pm 0.01 \mathrm{a}$ & $0.23 \pm 0.01 c$ & $0.87 \pm 0.09 c$ & $20.0 \pm 0.10 c$ & $0.51 \pm 0.07 \mathrm{e}$ \\
\hline $\mathrm{H} 2$ & $6.24 \pm 0.02 d$ & $16.37 \pm 0.90 \mathrm{~d}$ & $0.71 \pm 0.01 \mathrm{~d}$ & $24.43 \pm 1.11 b$ & $0.29 \pm 0.02 b c$ & $1.63 \pm 0.14 b$ & $20.7 \pm 0.43 c$ & $1.28 \pm 0.03 \mathrm{~d}$ \\
\hline $\mathrm{H} 3$ & $7.17 \pm 0.02 c$ & $21.46 \pm 2.87 c$ & $0.81 \pm 0.02 c$ & $23.53 \pm 6.23 b$ & $0.33 \pm 0.03 b$ & $1.56 \pm 0.09 b$ & $23.4 \pm 0.55 b$ & $2.12 \pm 0.03 c$ \\
\hline $\mathrm{H} 4$ & $7.44 \pm 0.03 b$ & $31.96 \pm 0.74 b$ & $0.88 \pm 0.06 b$ & $21.04 \pm 2.77 \mathrm{~b}$ & $0.32 \pm 0.01 b$ & $1.79 \pm 0.09 b$ & $23.3 \pm 0.25 b$ & $2.53 \pm 0.07 \mathrm{~b}$ \\
\hline H5 & $7.76 \pm 0.01 a$ & $46.71 \pm 2.17 \mathrm{a}$ & $1.22 \pm 0.01 \mathrm{a}$ & $26.02 \pm 2.09 b$ & $0.46 \pm 0.03 a$ & $2.09 \pm 0.19 a$ & $25.2 \pm 1.65 a$ & $3.58 \pm 0.05 a$ \\
\hline
\end{tabular}

SOM, soil organic matter; TN, total nitrogen; AN, available nitrogen; TP, total phosphorus; AP, available phosphorus; TK, total potassium; AK, available potassium. Values are shown as the means \pm SEM (standard error of the mean) calculated by three replicates. Different lower case letters in a single column indicate significant difference between treatments in individual biochar-amended soil sample tested by one-way analysis of variance (ANOVA) $(p<0.05)$. T represented ryegrass; $\mathrm{H}$ represented daylily; and the biochar dosages were $0 \%$ (control, T0/H0), $1 \%(\mathrm{~T} 1 / \mathrm{H} 1), 3 \%$ (T2/H2), 5\% (T3/H3), 7\% (T4/H4), and 9\% (T5/H5), respectively. 


\subsection{Soil Bacterial Abundance}

A total of $251703916 \mathrm{~S}$ rDNA sequences were obtained, and among which 1,144,162 and 1,372,877 sequences were obtained from the two test plants' soils, respectively. The $\mathrm{H}_{0}-2$ soil samples contained no reads because almost $80 \%$ were polluted by the hemerocallis, therefore, the $\mathrm{H}_{0}-2$ samples were precluded from further analysis of bacteria. After quality filtering the raw reads, 1,633,572 high quality reads were recorded, including 741,721 ryegrass soil sequences and 891,851 daylily soil sequences. The average read length of unique tag N50 was $446-458$ bp for ryegrass bacteria and $446-452 \mathrm{bp}$ for daylily bacteria. A total of 31,508 unique OTUs of soil bacteria were observed, including 12,350 ryegrass soils sequences and 19,158 daylily soils sequences, with an average of 906 OTUs per sample (Table 3).

The relative abundances of bacterial populations were detected from the observed frequencies of the corresponding sequence reads. In the result, with the relative abundance higher than $2 \%$, the rest were classified into other category, and the tags that could be identified to that level were classified into the 'unclassified' category. At the family level, the bacterial abundance was significantly higher than the controls (Figure 2). The relative abundances of two soils of both ryegrass and daylily growth increased with the biochar addition from CK to $9 \%$ treatments. The bacterial abundance increased with biochar addition, but had relatively lower values at the highest dosage. The relative abundance had the highest value at the $7 \%$ biochar addition rate, and had the lowest value at control treatments based on the values of the top 10 classified family (Figure 2). 
Table 3. Illumina Miseq sequencing bacterial data and bacterial community diversity both of soil planted with ryegrass (T) and daylily (H) indices (at $97 \%$ sequence similarity) based on $16 \mathrm{~S}$ rDNA gene.

\begin{tabular}{|c|c|c|c|c|c|c|c|c|c|}
\hline Sample ID & $\begin{array}{c}\text { Bacterial } \\
\text { Sequences }\end{array}$ & $\begin{array}{c}\text { Effective } \\
\text { Bacterial } \\
\text { Sequences }\end{array}$ & $\begin{array}{c}\text { Effective } \\
(\%)\end{array}$ & $\begin{array}{l}\text { Number of } \\
\text { Species }\end{array}$ & $\mathrm{ACE}^{\mathrm{c}}$ & $\begin{array}{c}\text { Chao } 1 \\
\text { Richness }\end{array}$ & $\begin{array}{c}\text { Shannon's } \\
\text { Diversity }\end{array}$ & $\begin{array}{c}\text { Simpson's } \\
\text { Diversity }\end{array}$ & Coverage $(\%)$ \\
\hline T0 & $46,154 \pm 3199$ & $43,822 \pm 2470$ & 95.03 & $703 \pm 102$ & $886.29 \pm 82.11 \mathrm{~ns}^{\mathrm{b}}$ & $878 \pm 91 b$ & $5.72 \pm 0.27 \mathrm{~b}$ & $0.9385 \pm 0.0106 b$ & 99.57 \\
\hline $\mathrm{T} 1$ & $44,976 \pm 2410$ & $43,761 \pm 2512$ & 97.28 & $657 \pm 50$ & $799.87 \pm 79.75$ & $788 \pm 68 \mathrm{a}^{\mathrm{a}}$ & $6.46 \pm 0.11 \mathrm{a}$ & $0.9727 \pm 0.0033 a$ & 99.65 \\
\hline $\mathrm{T} 2$ & $43,317 \pm 7064$ & $40,795 \pm 6620$ & 94.25 & $639 \pm 183$ & $793.40 \pm 209.10$ & $797 \pm 205 a b$ & $6.00 \pm 0.44 a b$ & $0.9515 \pm 0.0117 \mathrm{ab}$ & 99.60 \\
\hline $\mathrm{T} 3$ & $44,017 \pm 3616$ & $40,557 \pm 3517$ & 92.11 & $662 \pm 28$ & $807.73 \pm 30.99$ & $830 \pm 51 \mathrm{ab}$ & $6.00 \pm 0.13 \mathrm{ab}$ & $0.9513 \pm 0.0017 \mathrm{ab}$ & 99.59 \\
\hline $\mathrm{T} 4$ & $45,186 \pm 1675$ & $41,522 \pm 942$ & 91.95 & $770 \pm 80$ & $946.15 \pm 99.97$ & $974 \pm 91 a$ & $5.93 \pm 0.22 \mathrm{ab}$ & $0.9387 \pm 0.0169 \mathrm{ab}$ & 99.51 \\
\hline $\mathrm{T} 5$ & $39,326 \pm 1526$ & $36,783 \pm 1427$ & 93.54 & $687 \pm 65$ & $819.76 \pm 79.48$ & $823 \pm 72 \mathrm{ab}$ & $6.24 \pm 0.16 \mathrm{ab}$ & $0.9560 \pm 0.0049 \mathrm{ab}$ & 99.57 \\
\hline $\mathrm{HO}$ & $53,187 \pm 8790$ & $48,863 \pm 5699$ & 92.63 & $1033 \pm 175$ & $1260.92 \pm 220.03 b$ & $1282 \pm 193 b$ & $6.64 \pm 0.12 \mathrm{~ns}$ & $0.9578 \pm 0.0138 \mathrm{~ns}$ & 99.45 \\
\hline H1 & $60,186 \pm 5879$ & $56,018 \pm 5218$ & 93.11 & $1129 \pm 87$ & $1340.28 \pm 96.76 b$ & $1341 \pm 84 b$ & $6.65 \pm 0.15$ & $0.9594 \pm 0.0073$ & 99.52 \\
\hline $\mathrm{H} 2$ & $58,624 \pm 5592$ & $52,736 \pm 5727$ & 89.85 & $1441 \pm 49$ & $1690.14 \pm 68.64 a$ & $1693 \pm 67 a$ & $7.09 \pm 0.31$ & $0.9616 \pm 0.0112$ & 99.34 \\
\hline H3 & $53,098 \pm 1299$ & $49,754 \pm 1606$ & 93.69 & $1152 \pm 49$ & $1388.98 \pm 67.24 a b$ & $1408 \pm 85 a b$ & $7.01 \pm 0.22$ & $0.9664 \pm 0.0061$ & 99.44 \\
\hline $\mathrm{H} 4$ & $53,083 \pm 5527$ & $50,094 \pm 3767$ & 94.68 & $1056 \pm 181$ & $1286.53 \pm 238.19 b$ & $1311 \pm 233 b$ & $7.08 \pm 0.27$ & $0.9773 \pm 0.0057$ & 99.48 \\
\hline H5 & $58,344 \pm 7146$ & $56,106 \pm 7622$ & 96.02 & $918 \pm 65$ & $1128.02 \pm 66.25 b$ & $1135 \pm 74 b$ & $7.03 \pm 0.11$ & $0.9747 \pm 0.0023$ & 99.60 \\
\hline
\end{tabular}

a Values are shown as the means \pm SEM (standard error of the mean) calculated by three replicates. Different lower case letters in a single column indicate significant difference between treatments in individual biochar-amended soil sample tested by one-way ANOVA $(p<0.05) .{ }^{b}$ ns, no significance in this group. ${ }^{c}$ ACE represented Accumulation curve. T represented ryegrass; $\mathrm{H}$ represented daylily; and the biochar dosages were $0 \%$ (control, T0/H0), 1\% (T1/H1), 3\% (T2/H2), 5\% (T3/H3), 7\% (T4/H4), and 9\% (T5/H5), respectively. 


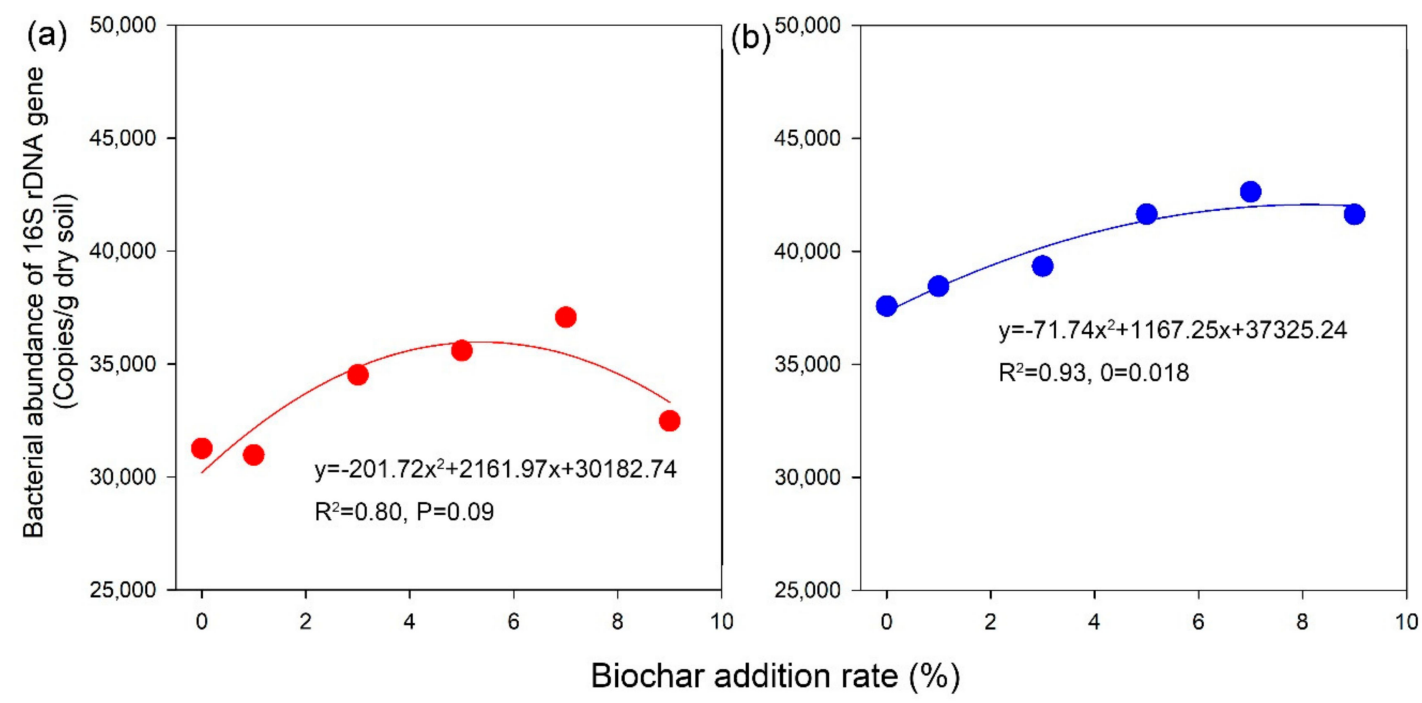

Figure 2. Effects of different biochar application on the relative abundance of the family in the soils of ryegrass (a) and daylily (b) growth.

\subsection{Soil Bacterial Community Diversity}

For the bacterial tag pyrosequencing dataset, bacterial community diversity was calculated according to relative abundance of OTUs at the 3\% sequence dissimilarity level. The alpha diversity, based on Shannon diversity, varied significantly $(p<0.05)$ among the different biochar addition regimes (Figure 3). The coverage values of all the soil samples were more than $98 \%$, which indicated that the current sequencing depth was adequate to obtain the bacterial diversity. Beta diversity of bacterial community revealed clear distinctions in bacterial populations of the two plant types. Micrococcaceae (ryegrass $24.53 \%$, daylily $16.20 \%$ ) was the dominant abundant and ubiquitous bacterial family occurring in the soil samples, followed by Oxalobacteraceae $(11.87 \%)$ and Nocardioidaceae $(7.89 \%)$ as the dominant families in the soils of ryegrass growth. In addition, Xanthomonadaceae $(6.94 \%)$ and Nocardioidaceae $(6.41 \%)$ were the dominant families in daylily soils. According to the weighted uniFrac distance analysis, the results indicated that the furthest distance of both the T5 and H5 treatments was obviously different from other treatments, and the highest similarities were found between the T3 and $\mathrm{T} 4$ treatments and between the $\mathrm{H} 2$ and $\mathrm{H} 3$ treatments in the family level (Figure 4). The results showed that the lower biochar treatments had a different bacterial community structure from the higher biochar treated soils. 

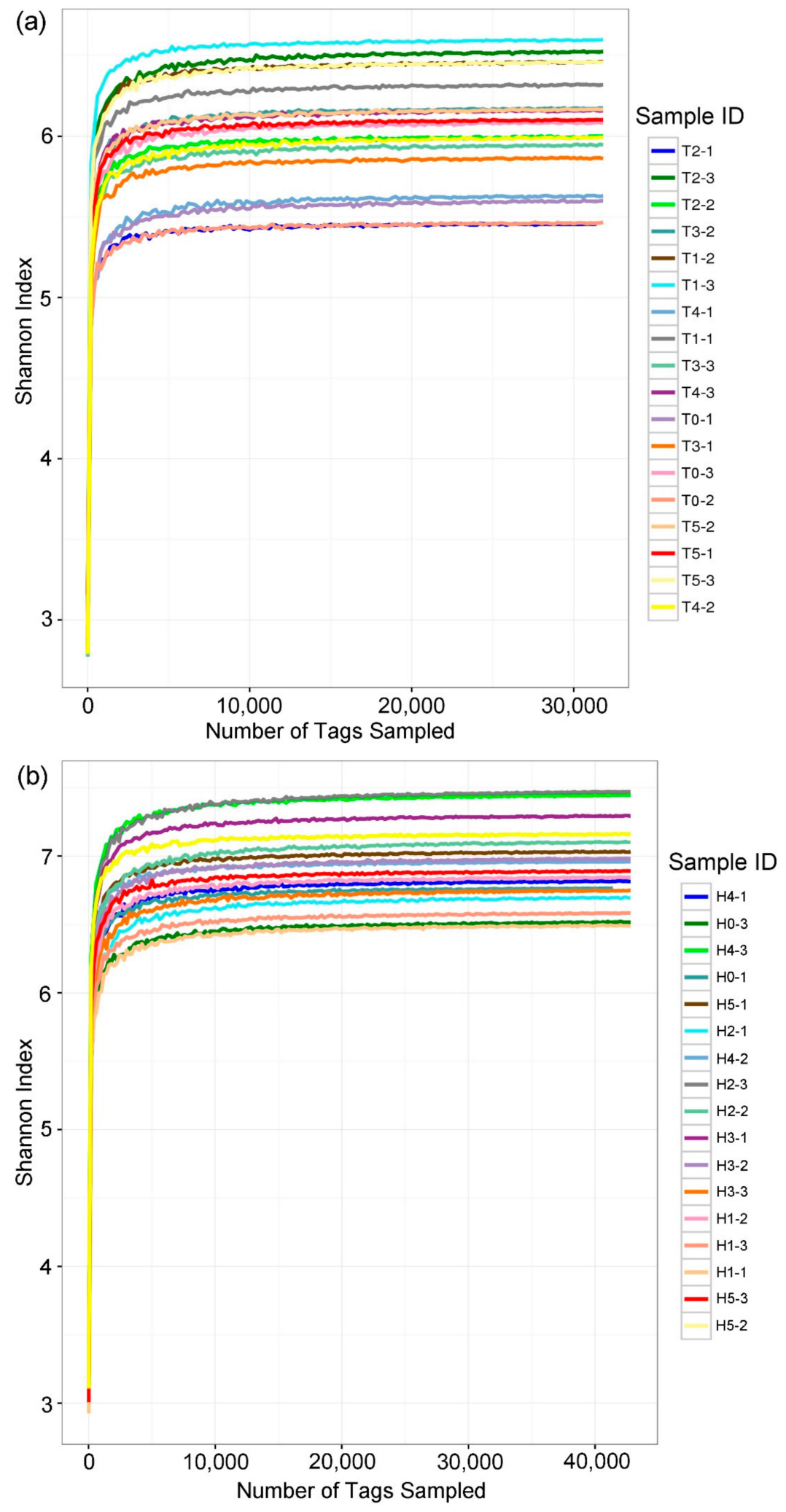

Figure 3. Shannon-rarefaction of operational taxonomic units (OTUs) clustered at $97 \%$ sequence observe across all soil samples, respectively. (a) T, ryegrass; (b) $\mathrm{H}$, daylily. The biochar dosages were $0 \%$ (control, T0/H0), 1\% (T1/H1), 3\% (T2/H2), 5\% (T3/H3), 7\% (T4/H4), and 9\% (T5/H5), respectively. 

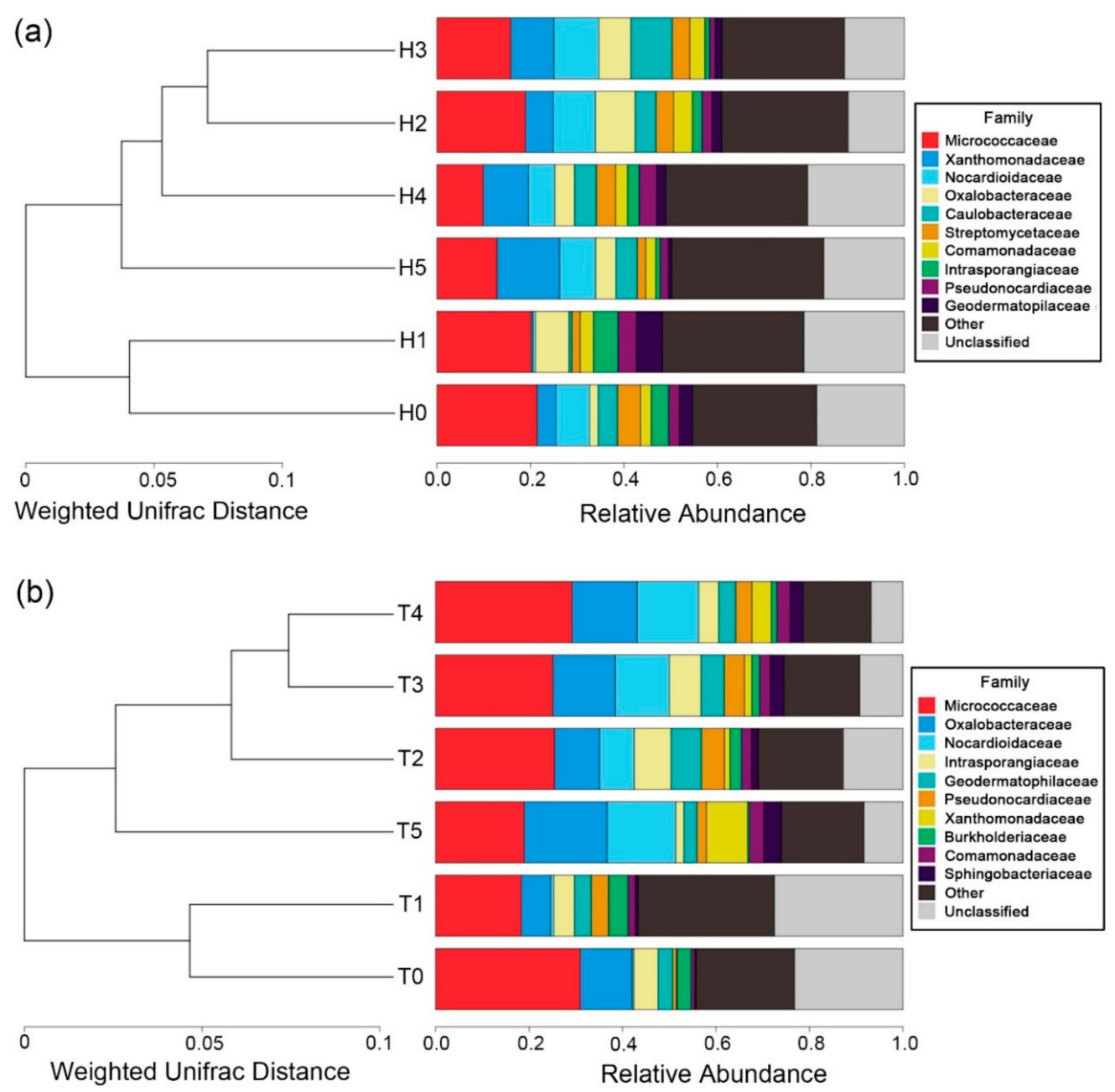

Figure 4. The weighted hierarchical clustering and relative abundances of soil bacteria at family levels, respectively. (a) $\mathrm{T}$, ryegrass; (b) $\mathrm{H}$, daylily. The biochar dosages were $0 \%$ (control, $\mathrm{T} 0 / \mathrm{H} 0), 1 \%$ (T1/H1), $3 \%$ (T2/H2), 5\% (T3/H3), 7\% (T4/H4), and 9\% (T5/H5), respectively.

\subsection{Soil Bacterial Community Structure}

The dominant bacterial family varied with biochar addition regimes (Figure 5). At the family level, we observed that Oxalobacteraceae, Nocardioidaceae, Pseudonocardiaceae, Comamonadaceae, and others were positively affected by biochar addition, and only Micrococcaceae was negatively related to biochar treatments in both test plants. In the soils planted with ryegrass, the abundances of three bacterial families, Micrococcaceae, Oxalobacteraceae, and Nocardioidaceae, significantly increased with biochar dosages (Figure 4). Similarly, in the soils planted with daylily, the three dominant abundant bacterial families were Micrococcaceae, Nocardioidaceae, and Xanthomonadaceae, and were substantially increased with biochar dosages. 

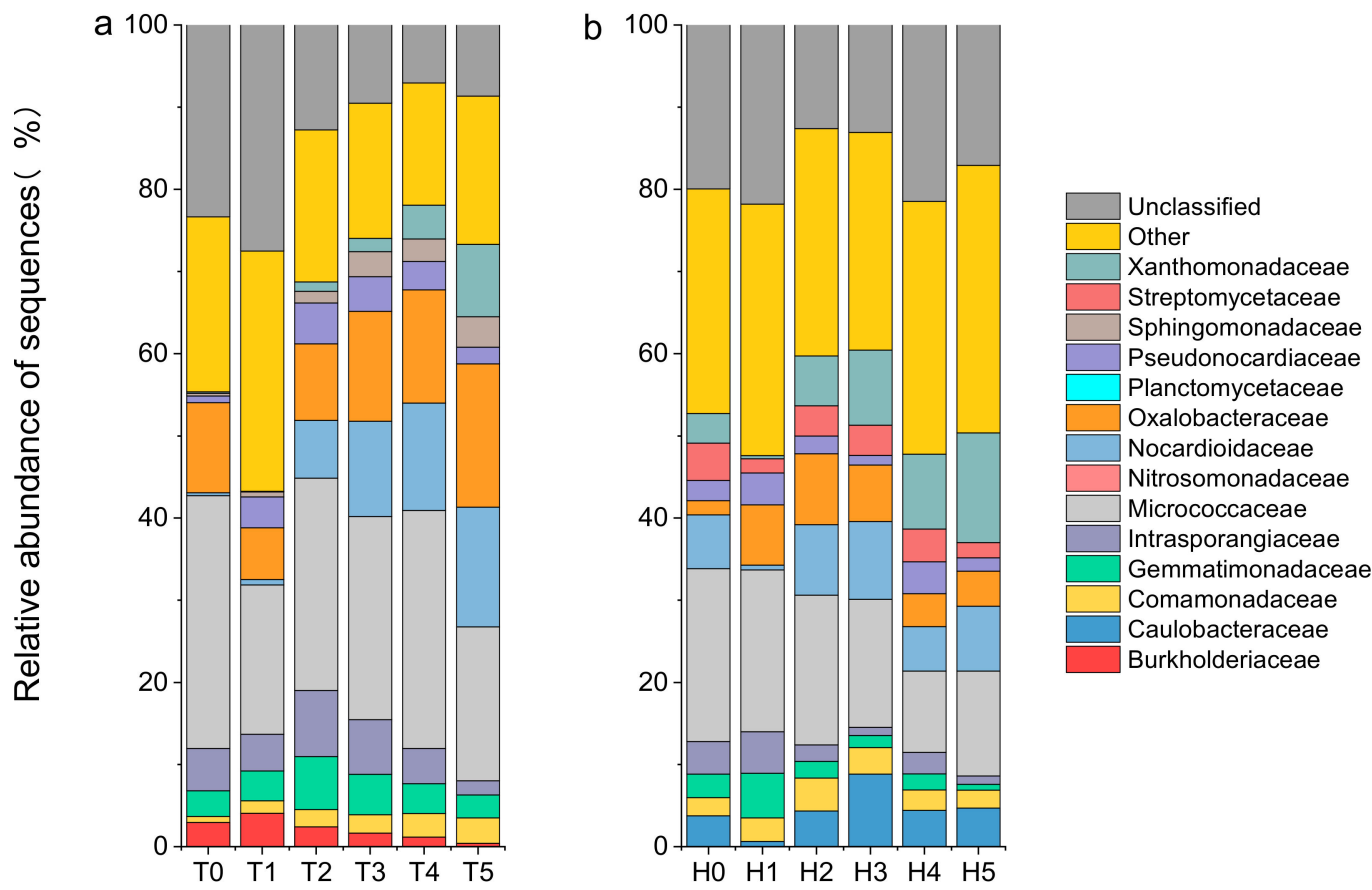

\section{Biochar treatments}

Figure 5. Bar chart of the relative abundance of bacterial at the family level in different biochar application regimes. (a) T, ryegrass; (b) $\mathrm{H}$, daylily. The biochar dosages were $0 \%$ (control, T0/H0), $1 \%$ (T1/H1), 3\% (T2/H2), 5\% (T3/H3), 7\% (T4/H4), and 9\% (T5/H5), respectively.

The results of canonical correspondence analysis (CCA) indicated that soil nutrients were mainly distributed in the first quadrant, except AN. As shown in Figure 6, over 70\% bacterial communities were arranged along the first axis on a CCA ordination biplot. Soil $\mathrm{pH}, \mathrm{AK}$, and $\mathrm{AP}$ were relatively near the first CCA axis, revealing that these three factors were the dominant environmental variables that influenced the bacterial communities with different biochar dosages. However, a negative relationship was found between soil AN and bacterial communities with different biochar addition. 


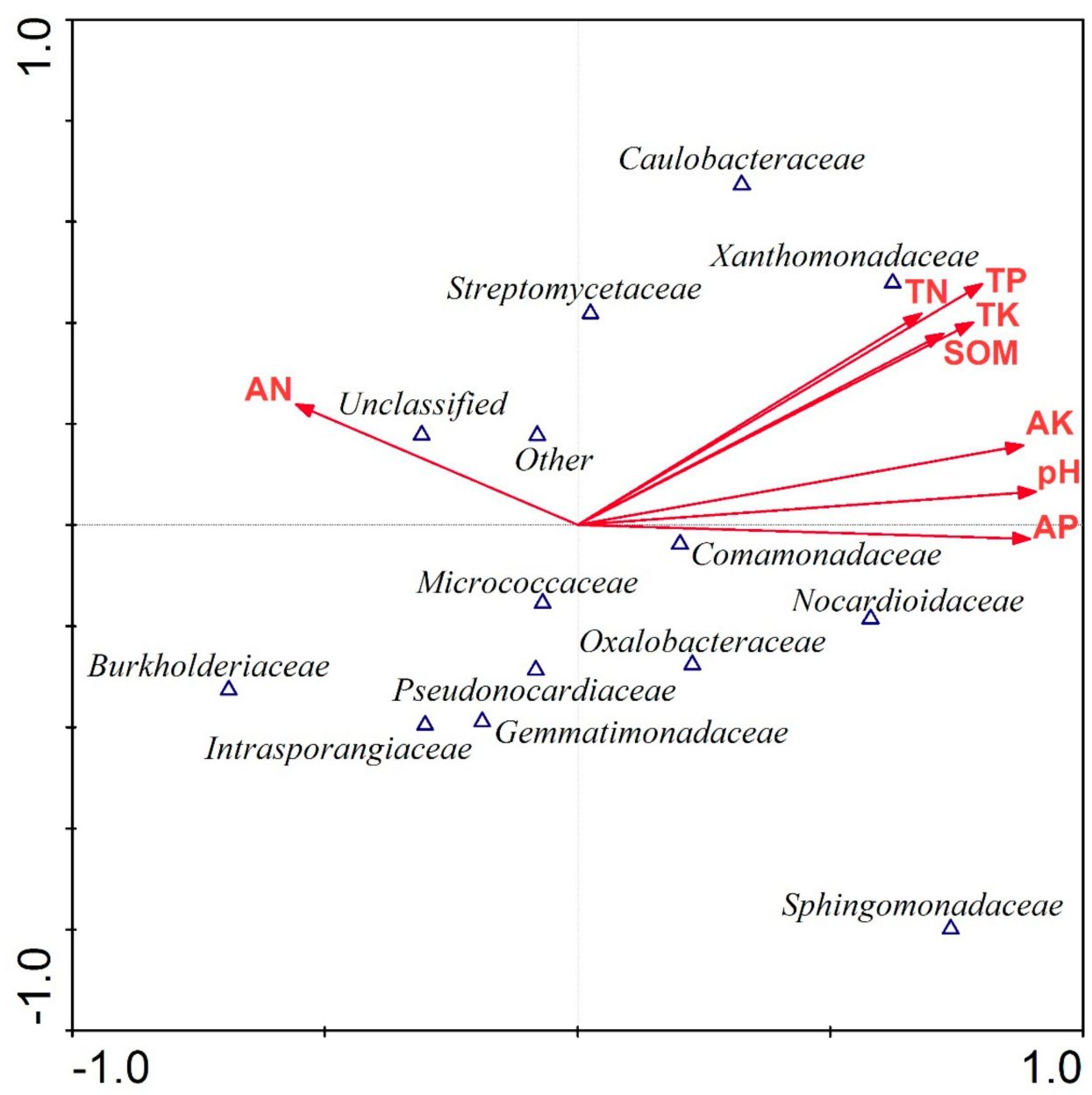

Figure 6. Biplot of canonical correspondence analysis (CCA) based on the relative abundance of bacterial communities and soil environmental factors. SOM, soil organic matter; TN, total nitrogen; AN, available nitrogen; TP, total phosphorus; AP, available phosphorus; TK, total potassium; AK, available potassium.

\section{Discussion}

\subsection{Effect of Biochar Addition on Soil Chemical Properties}

The result observed an increase in soil $\mathrm{pH}$ after adding biochar. It was owing to the feedstock characteristics of the apple-branch biochar of alkaline $\mathrm{pH}(10.09)$ and its pyrolysis temperature $\left(450{ }^{\circ} \mathrm{C}\right)$ in the study. The reason for the increase of $\mathrm{pH}$ in the biochar-added soils was the effect of the negatively charged phenolic, carboxyl, and hydroxyl groups on biochar surfaces [49]. In addition, the silicates, carbonates, and bicarbonates derived from biochar can bind $\mathrm{H}^{+}$ions, and thus remove them from soil solution, which also led to the increase in soil $\mathrm{pH}$ [22]. It has been well documented that biochar can improve soil nutrient and soil quality [50-52]. In this study, the SOM, TP, AP, TK, and AK in soils increased with biochar addition. This study deeply determined the impact of biochar in Karst yellow soil on seedling emergence of ryegrass and early plant growth of daylily in the relatively short term. However, different from some previous results [53,54], this result found that AN decreased with biochar addition dosages. It could be related to the high chemical stability and some physicochemical properties of biochar, such as $\mathrm{pH}$, surface chemical properties, pore structure and size distribution, specific surface area and particle, and other factors. [4,39]. Another reason is the uptake and adsorption of the soil AN by the need for nutrients for the growth of ryegrass and daylily (shallow-rooted 
plants). Specially, the nutrient uptake of the roots of test plants may induce the decreasing of soil AN concentration.

\subsection{Effect of Biochar Addition on Soil Bacterial Abundance}

The result supported our hypothesis that biochar addition altered bacterial abundance. Compared with the control, soil bacterial abundance obviously increased after biochar addition. In addition, the porous surface of biochar may provide a feasible habitat for microbes to protect them from predators [55]. Moreover, biochar can be as used an energy source caused by providing massive labile C, which is easily available to soil microbes for use in a relatively short period of time [56]. In this study, the soil pH increased from 5.42 to 7.90 (ryegrass) and from 5.45 to 7.76 (daylily), respectively (Table 2). The increased soil $\mathrm{pH}$ can increase microbial biomass, diversity, and nutrient bioavailability in acidic soils [57]. With the increase of biochar addition, the soil bacterial abundance significantly increased in $7 \%$ treatments during the study period. This was because of the relatively higher biochar addition treatments that altered soil environments via changing soil physicochemical properties. Furthermore, biochar provided more surface areas and pores to the habitat of microbes so that it can improve microbial biomass and abundance $[22,58]$. However, in our study, $9 \%$ biochar addition reduced the soil bacterial community abundance compared with the $7 \%$ treatments in both treated plants (Figure 2). This variation of soil bacterial abundance may be caused by the relative excessive biochar adding concentration of suppressed soil bacterial community abundance, similar to what was pointed out in [59], that excessive application of biochar might influence the movement and distribution of soil moisture and nutrients via decreasing soil wettability in a field experiment. Thereby, the result showed that the $7 \%$ biochar addition concentration is a suitable solution for Karst yellow soil.

\subsection{Effect of Biochar Addition on Soil Bacterial Community Structure}

The variations in soil microbial community structure depended on the soil properties, plants, moisture, temperature, and other climate factors. The weighted UniFrac distances (Figure 4) suggested a significant influence of biochar on soil bacterial community structure. This result indicated that the soil microbial community structure and function became more stable with biochar addition, which were caused by the improvement of soil properties after adding biochar [60-62]. These findings were owing to the shifts in soil environments (e.g., $\mathrm{pH}, \mathrm{SOM}, \mathrm{N}, \mathrm{P}$, and K). The Actinobacteria and Proteobacteria were the major contributing phyla, accounting for more than $50 \%$ of the relative abundance of the soil bacterial communities. Similar to the previous studies $[63,64]$, the increasing abundance of Actinobacteria owing to the biochar application could influence the proliferation of Actinobacteria and the other taxa. Proteobacteria played an important role in soil nutrient cycling and enriching in C-rich environments $[65,66]$. Therefore, it provided evidence of the increasing Proteobacteria induced by biochar. In addition, the release of labile soluble $C$ from biochar gave an alternative substrate for the microbial communities [67]. Biochar absorbed DOC (dissolved organic carbon) and released from SOM, preventing activity to microbial consumers [68]. In general, the variation of $\mathrm{pH}$ and oxidation potential owing to biochar-amended soil can affect the bacterial activity and community structure [21,69].

\subsection{Effect of Biochar Addition on Plants and Bacterial Community Composition}

The soil microbial community abundance and structure have been used as important indicators for soil quality evaluation [70]. In this study, the results of CCA revealed that soil properties varied with the different biochar addition rate, which strongly influenced the bacterial community composition. The results are in agreement with numerous previous studies reporting that the bacterial abundance and community structure were significantly influenced by soil $\mathrm{pH}, \mathrm{AK}$, and AP [71-73]. They were the dominant factors affecting soil bacterial community abundance and structure, which was also proved by the results of this study (Figure 6), because the soil properties of biochar-amended made the soil more feasible as a habitat for microbes [74]. However, owing to the inconsistency of studies concerning on this issue, the mechanisms of negative influences of AN in soil microbial community structure 
in biochar-amended soil need further research. The results found that the soil bacterial abundance can be affected by the availability of soil nutrients and carbon caused by the biochar properties $[4,19]$. The test plants influenced soil bacterial community structure owing to the different root-associated bacterial microbiomes by root exudates, which might have a vital role in determining the plants' response to disease stress via biochar incorporated into soil [75]. Furthermore, the positive correlation between soil nutrients and soil bacteria is in general agreement with previous research. Previous research revealed that the beneficial microorganisms enhanced plant growth through the chemical properties of biochar-stimulated positive responses to plant productivity [18]. However, we suggest that higher biochar addition dosage will put limitations on the growth of plants owing to the soil chemical properties, which were affected in yellow soil. Thus, it is necessary to pay more attention to the the positive effect of suitable biochar dosage addition on Karst yellow soil. Long-term field experiments are required to explore the influence and benefit of biochar amendment in Karst regions.

\section{Conclusions}

In this study, high-throughput sequencing coupled with bioinformatics methods were applied to the Karst yellow soil planted ryegrass and daylily with biochar addition. The results clearly demonstrated that biochar has a substantial effect on improving soil chemical properties and bacterial abundances and community structure. Taxonomic analysis identified that Micrococcaceae $(24.53 \%)$, Oxalobacteraceae (11.87\%), and Nocardioidaceae $(7.89 \%)$ were the dominant families in the soil of ryegrass growth and Micrococcaceae (16.20\%), Xanthomonadaceae (6.94\%), and Nocardioidaceae $(6.41 \%)$ were the dominant families in the soil of daylily growth. In both soils of planted ryegrass and daylily, the optimum soil bacterial abundance was found in $7 \%$ biochar dosage, but the lowest values were in the controls ( $0 \%)$. Soil $\mathrm{pH}, \mathrm{AP}$, and AK significantly influenced the soil bacterial abundance and community structure. Our results provide a promising strategy of biochar application to Karst yellow soil environment via enhancing the bacterial community composition. Biochar will be a potential soil fertility improving the soil environment in the southwest Karst area.

Author Contributions: Conceptualization and data collection, S.L.; Data curation, analysis and method, S.L. and D.S.; Funding acquisition, B.H.; Investigation, S.L. and Y.W.; Methodology, B.H. and S.L.; Writing-Original draft, S.L.; Writing-Review and editing, L.Y., T.L., B.H. and S.L. All authors have read and agreed to the published version of the manuscript.

Funding: This work was supported by the National Key Research and Development Program of China (2016YFC0502303) and the Department of Water Resources of Guizhou Province, China (KT201617).

Conflicts of Interest: The authors declare no conflict of interest.

\section{References}

1. O'Laughlin, J.; Mcelligott, K. Biochar for environmental management: Science and technology; Lehman, J., Joseph, S., Eds.; Earthscan: London, UK, 2009; pp. 535-536.

2. International Biochar Initiative. Standardized Product Definition and Product Testing Guidelines for Biochar that is Used in Soil; International Biochar Initiative: Canandaigua, NY, US, 2012.

3. Jeffery, S.; Verheijen, F.G.A.; Velde, M.V.D.; Bastos, A.C.A. Quantitative review of the effects of biochar application to soils on crop productivity using meta-analysis. Agric. Ecosyst. Environ. 2011, 144, $175-187$. [CrossRef]

4. Lehmann, J.; Rillig, M.C.; Thies, J.; Masiello, C.A.; Hockaday, W.C.; Crowley, D. Biochar effects on soil biota-a review. Soil Biol. Biochem. 2011, 43, 1812-1836. [CrossRef]

5. Park, J.H.; Ok, Y.S.; Kim, S.H.; Kang, S.W.; Cho, J.S.; Heo, J.S.; Delaune, R.D.; Seo, D.C. Characteristics of biochars derived from fruit tree pruning wastes and their effects on lead adsorption. J. Korean Soc. Appl. Biol. Chem. 2015, 58, 751-760. [CrossRef]

6. Rajapaksha, A.; Ahmad, M.; Vithanage, M.; Kim, K.R.; Chang, J.; Lee, S.; Ok, Y.S. The role of biochar, natural iron oxides, and nanomaterials as soil amendments for immobilizing metals in shooting range soil. Environ. Geochem. Health 2015, 37, 931-942. [CrossRef] [PubMed] 
7. Lehmann, J. Bio-energy in the black. Front Ecol. Environ. 2007, 5, 381-387. [CrossRef]

8. Shrestha, G.; Traina, S.J.; Swanston, C.W. Black carbon's properties and role in the environment: A comprehensive review. Sustainability 2010, 2, 294-320. [CrossRef]

9. Major, J.; Rondon, M.; Molina, D.; Riha, S.J.; Lehmann, J. Maize yield and nutrition during 4 years after biochar application to a Colombian savanna oxisol. Plant Soil 2010, 333, 117-128. [CrossRef]

10. Nguyen, T.T.N.; Wallace, H.M.; Xu, C.Y.; Zwieten, L.; Weng, Z.H.; Xu, Z.; Che, R.; Tahmasbian, I.; Hu, H.W.; Bai, S.H. The effects of short term, long term and reapplication of biochar on soil bacteria. Sci. Total Environ. 2018, 636, 142-151. [CrossRef]

11. Beluri, K.; Laxma, R.P.V.; Bojeong, K.; Soo, L.S.; Kumar, P.S.; Ki-Hyun, K. Benefits and limitations of biochar amendment in agricultural soils: A review. J. Environ. Manag. 2018, 227, 146-154.

12. Devare, M.; Londono, R.L.M.; Thies, J.E. Neither transgenic Bt maize (MON863) nor tefluthrin insecticide adversely affect soil microbial activity or biomass: A 3-year field analysis. Soil Biol. Biochem. 2007, 39, 2038-2047. [CrossRef]

13. Kolton, M.; Harel, Y.M.; Pasternak, Z.; Graber, E.R.; Elad, Y.; Cytryn, E. Impact of biochar application to soil on the root-associated bacterial community structure of fully developed greenhouse pepper plants. Appl. Environ. Microbiol. 2011, 77, 4924-4930. [CrossRef] [PubMed]

14. Joseph, S.; Xu, C.; Wallace, H.; Farrar, M.; Nguyen, T.N.; Bai, S.; Solaiman, Z. Biochar Production from Agricultural and Forestry Wastes and Microbial Interactions. In Current Developments in Biotechnology and Bioengineering: Solid Waste Management; Wong, J.W.C., Tyagi, R.D., Pandey, A., Eds.; Elsevier: Amsterdam, The Netherlands, 2016; pp. 443-473.

15. Spokas, K.A.; Novak, J.M.; Stewart, C.E.; Cantrell, K.B.; Uchimiya, M.; DuSaire, M.G.; Ro, K.S. Qualitative analysis of volatile organic compounds on biochar. Chemosphere 2011, 85, 869-882. [CrossRef] [PubMed]

16. Zhu, X.; Chen, B.; Zhu, L.; Xing, B. Effects and mechanisms of biochar-microbe interactions in soil improvement and pollution remediation: A review. Environ. Pollut. 2017, 227, 98-115. [CrossRef]

17. Wang, X.B.; Song, D.L.; Liang, G.Q.; Zhang, Q.; Ai, C.; Zhou, W. Maize biochar addition rate influences soil enzyme activity and microbial community composition in a fluvoaquic soil. Appl. Soil Ecol. 2015, 96, 265-272. [CrossRef]

18. Graber, E.R.; Harel, Y.M.; Kolton, M.; Cytryn, E.; Silber, A.; David, D.R.; Tsechansky, L.; Borenshtein, M.; Elad, Y. Biochar impact on development and productivity of pepper and tomato grown in fertigated soilless media. Plant Soil 2010, 337, 481-496. [CrossRef]

19. Quilliam, R.S.; Glanville, H.C.; Wade, S.C.; Jones, D.L. Life in the 'charosphere' - does biochar in agricultural soil provide a significant habitat for microorganisms? Soil Biol. Biochem. 2013, 65, 287-293. [CrossRef]

20. Yu, J.; Deem, L.M.; Crow, S.E.; Deenik, J.L.; Penton, C.R. Biochar application influences microbial assemblage complexity and composition due to soil and bioenergy crop type interactions. Soil Biol. Biochem. 2018, 117, 97-107. [CrossRef]

21. Chen, J.H.; Liu, X.Y.; Zheng, J.W.; Zhang, B.; Lu, H.F.; Chi, Z.Z.; Pan, G.X.; Li, L.Q.; Zheng, J.F.; Zhang, X.H.; et al. Biochar soil amendment increased bacterial but decreased fungal gene abundance with shifts in community structure in a slightly acid rice paddy from Southwest China. Appl. Soil. Ecol. 2013, 71, 33-44. [CrossRef]

22. Gul, S.; Whalen, J.K.; Thomas, B.W.; Sachdeva, V.; Deng, H. Physico-chemical properties and microbial responses in biochar-amended soils: Mechanisms and future directions. Agric. Ecosyst. Environ. 2015, 206, 46-59. [CrossRef]

23. Lu, H.F.; Lashari, M.S.; Liu, X.Y.; Ji, H.S.; Li, L.Q.; Zheng, J.F.; Kibue, G.W.; Joseph, S.; Pan, G.X. Changes in soil microbial community structure and enzyme activity with amendment of biochar-manure compost and pyroligneous solution in a saline soil from central China. Eur. J. Soil Biol. 2015, 70, 67-76. [CrossRef]

24. Hu, L.; Cao, L.X.; Zhang, R.D. Bacterial and fungal taxon changes in soil microbial community composition induced by short-term biochar amendment in red oxidized loam soil. World J. Microb. Biot. 2014, 30, 1085-1092. [CrossRef] [PubMed]

25. Hale, L.; Luth, M.; Crowley, D. Biochar characteristics relate to its utility as an alternative soil inoculum carrier to peat and vermiculite. Soil Biol. Biochem. 2015, 81, 228-235. [CrossRef]

26. Rutigliano, F.A.; Romano, M.; Marzaioli, R.; Baglivo, I.; Baronti, S.; Miglietta, F.; Castaldi, S. Effect of biochar addition on soil microbial community in a wheat crop. Eur. J. Soil Biol. 2014, 60, 9-15. [CrossRef] 
27. Manolikaki, I.; Diamadopoulos, E. Ryegrass yield and nutrient status after biochar application in two Mediterranean soils. Arch. Agro. Soil Sci. 2016, 63, 1093-1107. [CrossRef]

28. Liu, C.C.; Liu, Y.G.; Guo, K.; Wang, S.J.; Liu, H.M.; Zhao, H.W.; Qiao, X.G.; Hou, D.J.; Li, S.B. Aboveground carbon stock, allocation and sequestration potential during vegetation recovery in the karst region of southwestern China: A case study at a watershed scale. Agric. Ecosyst. Environ. 2016, 235, 91-100. [CrossRef]

29. Bai, X.Y.; Wang, S.J.; Xiong, K.N. Assessing spatial-temporal evolution processes of karst rocky desertification land: Indications for restoration strategies. Land Degrad. Dev. 2013, 24, 47-56. [CrossRef]

30. Yan, Y.J.; Dai, Q.H.; Yuan, Y.F.; Peng, X.D.; Zhao, L.S.; Yang, J. Effects of rainfall intensity on runoff and sediment yields on bare slopes in a karst area, SW China. Geoderma 2018, 330, 30-40. [CrossRef]

31. Zhang, X.Q.; Hu, M.C.; Guo, X.Y.; Yang, H.; Zhang, Z.K.; Zhang, K.L. Effects of topographic factors on runoff and soil loss in Southwest China. Catena 2018, 160, 394-402. [CrossRef]

32. Carlson, J.; Saxena, J.; Basta, N.; Hundal, L.; Busalacchi, D.; Dick, R.P. Application of organic amendments to restore degraded soil: Effects on soil microbial properties. Environ. Monit. Assess. 2015, 187, 1-15. [CrossRef]

33. Dai, Q.; Peng, X.; Yang, Z.; Zhao, L. Runoff and erosion processes on bare slopes in the karst rocky desertification area. Catena 2017, 152, 218-226. [CrossRef]

34. El-Naggar, A.; Lee, S.S.; Rinklebe, J.; Farooq, M.; Song, H.; Sarmah, A.K.; Zimmerman, A.R.; Ahmad, M.; Shaheen, S.M.; Ok, Y.S. Biochar application to low fertility soils: A review of current status, and future prospects. Geoderma 2019, 337, 536-554. [CrossRef]

35. Prendergast-Miller, M.T.; Duvall, M.; Sohi, S.P. Biochar-root interactions are mediated by biochar nutrient content and impacts on soil nutrient availability. Eur. J. Soil Sci. 2014, 65, 173-185. [CrossRef]

36. Yu, H.W.; Zou, W.X.; Chen, J.J.; Chen, H.; Yu, Z.B.; Huang, J.; Tang, H.R.; Wei, X.Y.; Gao, B. Biochar amendment improves crop production in problem soils: A review. J. Environ. Manag. 2019, 232, 8-21. [CrossRef] [PubMed]

37. Verheijen, F.G.A.; Jeffery, S.; Bastos, A.C.; Velde, M.V.D.; Diafas, I. Biochar application to soils: A critical scientific review of effects on soil properties, processes and functions. In EUR 24099 EN; Office for the Official Publications of the European Communities: Luxembourg, 2009.

38. Sun, C.X.; Chen, X.; Cao, M.; Li, Q.; Zhang, Y.L. Growth and metabolic responses of maize roots to straw biochar application at different rates. Plant Soil 2017, 416, 487-502. [CrossRef]

39. Gale, N.V.; Thomas, S.C. Dose-dependence of growth and ecophysiological responses of plants to biochar. Sci. Total Environ. 2019, 658, 1344-1354. [CrossRef]

40. Lu, R.K. Analytical Methods of Soil Agrochemistry; China Agricultural Science and Technology Press: Beijing, China, 1999. (In Chinese)

41. Institute of Soil Sciences, Chinese Academy of Sciences (ISSCAS). Physical and Chemical Analysis Methods of Soils; Shanghai Science Technology Press: Shanghai, China, 1978. (In Chinese)

42. Miranda, K.M.; Espey, M.G.; Wink, D.A. A rapid, simple spectrophotometric method for simultaneous detection of nitrate and nitrite. Nitric. Oxide 2001, 5, 62-71. [CrossRef]

43. Magoč, T.; Salzberg, S.L. FLASH: Fast length adjustment of short reads to improve genome assemblies. Bioinformatics 2011, 27, 2957-2963. [CrossRef]

44. Edgar, R.C. UPARSE: Highly accurate OTU sequences from microbial amplicon reads. Nat. Methods 2013, 10, 996. [CrossRef]

45. R Development Core Team. R: A Language and Environment for Statistical Computing; R Foundation for Statistical Computing: Vienna, Austria, 2015.

46. Wang, Q.; Garrity, G.M.; Tiedje, J.M.; Cole, J.R. Naïve Bayesian classifier for rapid assignment of rRNA sequences into the new bacterial taxonomy. Appl. Environ. Microbiol. 2007, 73, 5261-5267. [CrossRef]

47. Pruesse, E.; Quast, C.; Knittel, K.; Fuchs, B.M.; Ludwig, W.; Peplies, J.; Glöckner, F.O. SILVA: A comprehensive online resource for quality checked and aligned ribosomal RNA sequence data compatible with ARB. Nucleic Acids Res. 2007, 35, 7188-7196. [CrossRef]

48. Caporaso, J.G.; Kuczynski, J.; Stombaugh, J.; Bittinger, K.; Bushman, F.D.; Costello, E.K.; Knight, R. Qiime allows analysis of high-throughput community sequencing data. Nat. Methods 2010, 7, 335-336. [CrossRef] [PubMed]

49. Brewer, C.E.; Brown, R.C. Biochar. In Comprehensive Renewable Energy; Sayigh, A., Ed.; Elsevier: Oxford, UK, 2012; pp. 357-384.

50. Lal, R. Soils and food sufficiency: A review. Agron. Sustain. Dev. 2009, 29, 113-133. [CrossRef] 
51. Zheng, H.; Wang, Z.Y.; Deng, X.; Herbert, S.; Xing, B.S. Impacts of adding biochar on nitrogen retention and bioavailability in agricultural soil. Geoderma 2013, 206, 32-39. [CrossRef]

52. Liu, L.; Wang, Y.; Yan, X.; Li, J.; Jiao, N.; Hu, S. Biochar amendments increase the yield advantage of legume-based intercropping systems over monoculture. Agric. Ecosyst. Environ. 2017, 237, 16-23. [CrossRef]

53. Arif, M.; Ilyas, M.; Riaz, M.; Ali, K.; Shah, K.; Ul Haq, I.; Fahad, S. Biochar improves phosphorus use efficiency of organic-inorganic fertilizers, maize-wheat productivity and soil quality in a low fertility alkaline soil. Field Crop. Res. 2017, 214, 25-37. [CrossRef]

54. Zhou, Z.D.; Gao, T.; Zhu, Q.; Yan, T.T.; Li, D.C.; Xue, J.H.; Wu, Y.B. Increases in bacterial community network complexity induced by biochar-based fertilizer amendments to karst calcareous soil. Geoderma 2019, 337, 691-700. [CrossRef]

55. Pietikäinen, J.; Kiikkilä, O.; Fritze, H. Charcoal as a habitat for microbes and its effects on the microbial community of the underlying humus. Oikos 2000, 89, 231-242. [CrossRef]

56. Smith, J.L.; Collins, H.P.; Bailey, V.L. The effect of young biochar on soil respiration. Soil Biol. Biochem. 2010, 42, 2345-2347. [CrossRef]

57. Pietri, J.C.A.; Brookes, P.C. Relationships between soil $\mathrm{pH}$ and microbial properties in a UK arable soil. Soil Biol. Biochem. 2008, 40, 1856-1861. [CrossRef]

58. Ameloot, N.; Graber, E.R.; Verheijen, F.G.A.; DeNeve, S. Interactions between biochar stability and soil organisms: Review and research needs. Eur. J. Soil. Sci. 2013, 64, 379-390. [CrossRef]

59. Li, C.J.; Xiong, Y.W.; Qu, Z.Y.; Xu, X.; Huang, Q.Z.; Huang, G.H. Impact of biochar addition on soil properties and water-fertilizer productivity of tomato in semi-arid region of Inner Mongolia, China. Geoderma 2018, 331, 100-108. [CrossRef]

60. Gomez, J.D.; Denef, K.; Stewart, C.E.; Zheng, J.; Cotrufo, M.F. Biochar addition rate influences soil microbial abundance and activity in temperate soils. Eur. J. Soil Sci. 2014, 65, 28-39. [CrossRef]

61. Mitchell, P.J.; Simpson, A.J.; Soong, R.; Simpson, M.J. Shifts in microbial community and water-extractable organic matter composition with biochar amendment in a temperate forest soil. Soil Biol. Biochem. 2015, 81, 244-254. [CrossRef]

62. Zhang, C.S.; Lin, Y.; Tian, X.Y.; Xu, Q.; Chen, Z.H.; Lin, W. Tobacco bacterial wilt suppression with biochar soil addition associates to improved soil physiochemical properties and increased rhizosphere bacteria abundance. Appl. Soil Ecol. 2017, 112, 90-96. [CrossRef]

63. O’Neil, B.; Grossman, J.; Tsai, M.T.; Gomes, J.E.; Lehmann, J.; Peterson, J.; Neves, E.; Thies, J.E. Bacterial community composition in Brazilian Anthrosols and adjacent soils characterized using culturing and molecular identification. Microb. Ecol. 2009, 58, 23-35. [CrossRef]

64. Prayogo, C.; Jones, J.E.; Baeyens, J.; Bending, G.D. Impact of biochar on mineralisation of C and N from soil and willow litter and its relationship with microbial community biomass and structure. Biol. Fertil. Soils 2014, 50, 695-702. [CrossRef]

65. Xu, N.; Tan, G.C.; Wang, H.Y.; Gai, X.P. Effect of biochar additions to soil on nitrogen leaching, microbial biomass and bacterial community structure. Eur. J. Soil Biol. 2016, 74, 1-8. [CrossRef]

66. Ren, C.J.; Wang, T.; Xu, Y.D.; Deng, J.; Zhao, F.Z.; Yang, G.H.; Han, X.H.; Feng, Y.Z.; Ren, G.X. Differential soil microbial community responses to the linkage of soil organic carbon fractions with respiration across land-use changes. For. Ecol. Manag. 2018, 409, 170-178. [CrossRef]

67. Jones, D.L.; Murphy, D.V.; Khalid, M.; Ahmad, W.; Edwards-Jones, G.; DeLuca, T.H. Short-term biochar-induced increase in soil $\mathrm{CO}_{2}$ release is both biotically and abiotically mediated. Soil Biol. Biochem. 2011, 43, 1723-1731. [CrossRef]

68. Jones, D.L.; Edwards-Jones, G.; Murphy, D.V. Biochar mediated alterations in herbicide breakdown and leaching in soil. Soil Biol. Biochem. 2011, 43, 804-813. [CrossRef]

69. McCormack, S.A.; Ostle, N.; Bardgett, R.D.; Hopkins, D.W.; Vanbergen, A.J. Biochar in bioenergy cropping systems:impacts on soil faunal communities and linked ecosystem processes. Gcb. Bioenergy 2013, 5, 81-95. [CrossRef]

70. Paz-Ferreiro, J.; Fu, S.L. Biological indices for soil quality evaluation: Perspectives and limitations. Land Degrad. Dev. 2016, 27, 14-25. [CrossRef]

71. Sheng, Y.Q.; Zhu, L.Z. Biochar alters microbial community and carbon sequestration potential across different soil pH. Sci. Total Environ. 2018, 622, 1391-1399. [CrossRef] [PubMed] 
72. Liu, X.Y.; Ye, Y.X.; Liu, Y.M.; Zhang, A.F.; Zhang, X.H.; Li, L.Q.; Pan, G.X.; Kibue, G.W.; Zheng, J.F.; Zheng, J.W. Sustainable biochar effects for low carbon crop production: A 5-crop season field experiment on a low fertility soil from Central China. Agric. Syst. 2014, 129, 22-29. [CrossRef]

73. Nielsen, S.; Minchin, T.; Kimber, S.; Van Zwieten, L.; Gilbert, J.; Munroe, P.; Joseph, S.; Thomas, T. Comparative analysis of the microbial communities in agricultural soil amended with enhanced biochars or traditional fertilisers. Agric. Ecosyst. Environ. 2014, 191, 73-82. [CrossRef]

74. Shaaban, M.; Zwieten, L.V.; Bashir, S.; Younas, A.; Núñez-Delgado, A.; Chhajro, M.A.; Kubar, K.A.; Ali, U.; Rana, M.S.; Mehmood, M.A.; et al. A concise review of biochar application to agricultural soils to improve soil conditions and fight pollution. J. Environ. Manag. 2018, 228, 429-440. [CrossRef]

75. Akhter, A.; Hage-Ahmed, K.; Soja, G.; Steinkellner, S. Compost and biochar alter mycorrhization, tomato root exudation, and development of Fusarium oxysporum f. sp. lycopersici. Front. Plant Sci. 2015, 6, 529. [CrossRef]

(C) 2020 by the authors. Licensee MDPI, Basel, Switzerland. This article is an open access article distributed under the terms and conditions of the Creative Commons Attribution (CC BY) license (http://creativecommons.org/licenses/by/4.0/). 